\title{
Optimalisasi Distribusi Harga Tiket Pesawat berdasarkan Kepadatan Rute Menggunakan Algoritma Genetika
}

\author{
http://dx.doi.org/10.28932/jutisi.v5i2.1756
}

\author{
Sri Hutamy Novianti ${ }^{\bowtie}$, Esmeralda C. Djamal ${ }^{* 2}$, Agus Komarudin ${ }^{3}$ \\ ${ }^{\#}$ Mahasiswa Program Studi Informatika, Universitas Jenderal Achmad Yani \\ Jl. Terusan Jend. Sudirman, Cibeber, Kec. CImahi Sel., Kota Cimahi, Jawa Barat \\ 1 srihutamy280@gmail.com \\ ${ }^{2}$ esmeraldacdegmail.com \\ ${ }^{3}$ agus. komarudinelecture.unjani.ac.id
}

\begin{abstract}
The development of the aviation industry in Indonesia in the past decade has risen sharply. One of the impacts of the development of the aviation industry was the presence of a multilevel tariff concept. Where the concept is the variation in ticket prices in one class with slightly different facilities such as the difference in penalty fees for making refunds and rebooking. The concept of multilevel rates is usually referred to as sub-class rates. One application of the sub-class tariffs in economic classes are divided into four types of sub-classes special promo sub-classes, promo sub-classes, then affordable sub-class and flexible sub-class. One optimization method of getting a combination that meets the requirements without having to try all possibilities is the Genetic Algorithm. The chromosomes built represent 10 subclasses on 9 routes so that they have 90 genes. The use of genetic algorithms originated from the generation of an initial population of 8 chromosomes with a length of 90 genes performed randomly, evaluation of the compatibility function was then selected using the Rank-based fitness technique, crosses using Multi-Point Crossover, mutations with the Mutation Insertion technique. The system built was tested with two conditions each of eight tests with 100 generations. First, the test uses the mutation method of three subclass codes on four routes at a capacity of 150 seats, obtained the largest match value of Rp. $\mathbf{7 5 0 , 7 5 2 , 2 0 0}$ and the smallest Rp. $662,283,100$. And testing with the mutation method of three subclass codes on eight routes of 150 seat capacity obtained the largest match value of $R p .763,265,300$ and the smallest $R p$. $547,396,200$. The results of testing the mutation method on eight routes resulted in a higher match value compared to the mutation method on four routes. The software system has been implemented so that it can provide recommendations on the number of ticket passes distributed in the economic subclass.
\end{abstract}

Keywords - Distribution of number of tickets, Genetic algorithm, Route, Optimization, Sub-class.

\section{Pendahuluan}

Pada rentang 1990-an, demand masyarakat terhadap transportasi udara masih tergolong rendah, hal itu ditandai dengan banyaknya maskapai penerbangan yang gulung tikar, salah satu alasan penyebabnya adalah beberapa maskapai yang melayani penerbangan domestik belum menerapkan sistem sub-kelas dan hanya menerapkan ekonomi dan kelas bisnis sehingga harga yang ditawarkan tidak beragam bahkan tidak terjangkau oleh masyarakat. Namun beberapa tahun terakhir, demand masyarakat Indonesia sudah semakin meningkat [1]. Sehingga pertumbuhan industri penerbangan meningkat, namun hal itu menyebabkan tingginya kompetisi para maskapai penerbangan dan mendorong maskapai penerbangan untuk mampu melakukan pengelolaan pendapatan agar tetap masuk ke dalam berbagai jenis segmen pelanggan dengan tetap menyediakan harga yang bersaing dan adanya alokasi jumlah kursi penumpang yang sesuai untuk penerbangan tertentu pada waktu dan kondisi yang tepat.

Salah satu dampak dari perkembangan industri penerbangan tersebut yaitu kehadiran konsep tarif bertingkat. Tarif bertingkat adalah variasi harga tiket dalam satu kelas yang sama dengan fasilitas yang sedikit berbeda seperti perbedaan biaya penalti untuk melakukan refund dan rebook. Konsep tarif bertingkat biasanya disebut dengan tarif subkelas. Salah satu penerapan dari tarif sub-kelas tersebut dalam kelas ekonomi dibagi ke dalam empat jenis sub-kelas yang diwakili dengan huruf alfabet. Seperti "Y" untuk subkelas fleksibel, huruf "B", "M", "K", "N" pada sub-kelas affordable yang dibedakan berdasarkan harga dengan fasilitas yang sama, kemudian huruf "Q", "T","V" dan "S" pada sub-kelas promo dan huruf "L" pada sub-kelas spesial promo.

Maskapai penerbangan menyediakan kapasitas seat atau kapasitas kursi untuk kelas ekonomi dalam satu pesawat sangat beragam hal itu di sebabkan karena banyaknya jenis pesawat yang digunakan dalam penerbangan, maskapai bisa menyediakan jumlah seat sebanyak 150 seat, 263 seat, 186 seat, 162 seat, 96 seat, 70 seat dan 360 seat untuk kelas ekonomi. Salah satunya 150 seat, untuk menjual 150 seat tersebut masakapai membagi jumlah tiket kedalam 10 subkelas yaitu kode "L", "Q", “T", "V”, "S", "B”, “M”, "K”, "N", "Y". Kode sub-kelas tersebut dibedakan berdasarkan 
harga, maskapai mengatur jumlah tiket yang harus dijual untuk setiap kode sub-kelas, namun sulit untuk mendapatkan kombinasi jumlah tiket 10 sub-kelas yang dapat menghasilkan keuntungan yang maksimal dan tiket dapat terdistribusi.

Mengatur jumlah tiket yang harus dijual pada 10 subkelas dapat menjadi salah satu strategi untuk memaksimalkan pendapatan dan meningkatkan jumlah pembelian tiket. Karena jumlat tiket yang dijual pada setiap sub-kelas ditentukan berdasarkan pengalaman dan pertimbangan sesaat dengan jumlah tiket yang tidak beragam, Sehingga, dibutuhkan suatu model komputasi untuk mencari kombinasi jumlah tiket setiap sub-kelas yang terdistribusi sehingga dapat menghasilkan keuntungan optimal dan jumlah tiket terdistribusi.

Kombinasi jumlah tiket setiap sub-kelas dilakukan pada sembilan rute dengan kemungkinan kombinasi yang sangat banyak sehingga dibutuhkan metode dengan ruang pencarian yang luas. Salah satunya metode Algoritma Genetika dimana metode tersebut merupakan metode pencarian solusi yang sesuai dengan kriteria dari banyak kombinasi solusi yang ada tanpa harus menguji satu-persatu untuk mendapatkannya. Keberhasilan Algoritma Genetika dalam memperoleh solusi, sangat sensitif terhadap pemilihan atribut yang relevan terhadap bentuk struktur kromosom yang mewakili suatu solusi [2].

Penelitian mengenai penentuan subclass berdasarkan tipe pesawat untuk menentukan harga tiket pada subclass yang dapat menghasilkan pendapatan minimum atau titik impas, jumlah penumpang minimum yang harus diangkut, persentase jumlah seat yang harus terisi agar mencapai titik impas berdasarkan 4 tipe pesawat [1].

Algoritma Genetika untuk penentuan komposisi bahan pangan untuk diet penyakit ginjal dan saluran kemih mencari komposisi bahan pangan yang optimal untuk mencukupi kebutuhan gizi dalam 1 hari bagi yang sedang melakukan diet untuk penyakit ginjal dan saluran kemih [3].

Algoritma Genetika untuk menyelesaikan coin problem untuk memecahkan masalah dalam mencari jumlah kombinasi pecahan optimum untuk mendapatkan nilai uang dengan kombinasi beberapa pecahan mata uang yang berbeda [4], optimalisasi perancangan jalur pembibitan [5] membandingkan metode Genetic Greedy Algorithm (GGA), Genetic Algorithm (GA) dan Common sequence method (CSM) dalam hal pengoptimalan perancangan jalur dan perhitungan waktu untuk pembibitan dari nampan kepadatan tinggi ke nampan berkepadatan rendah [5].

Penelitian ini membangun sistem untuk optimalisasi jumlah tiket pesawat pada 10 sub-class menggunakan Algoritma Genetika melalui tahapan pembuatan populasi awal, menentukan fungsi kecocokan, seleksi, persilangan, mutasi dan evaluasi. Kemampuan Algoritma Genetika dapat memberikan solusi yang optimal dari kombinasi jumlah tiket pesawat berdasarkan jenis sub-kelas. Hasil penelitian dapat dimanfaatkan untuk mengoptimalkan dan meningkatkan efektivitas dalam penentuan jumlah tiket pesawat yang dijual pada 10 sub-kelas 9 rute sehingga dapat mengoptimalkan keuntungan dan meningkatkan penjualan tiket.

\section{TINJAUAN PUSTAKA}

Algoritma Genetika adalah teknik pencarian heuristik yang didasarkan pada gagasan evolusi seleksi dan genetika. Algoritma ini memanfaatkan proses seleksi alamiah yang dikenal dengan proses evolusi. Dalam proses evolusi, individu secara terus menerus mengalami perubahan gen untuk menyesuaikan dengan lingkungan hidupnya dan individu yang kuat akan mampu bertahan dalam evolusi.

Proses [6].

Siklus algoritma Genetika dibagi menjadi dua bagian yaitu pra proses dan siklus genetika. Tahap pra proses diawali dengan pengkodean isi gen, selanjutnya merepresentasikan solusi dalam struktur kromosom, Representasi Kromosom yaitu proses yang mewakili solusi dari permasalahan yang akan diselesaikan menggunakan algoritma genetika. Kemudian fungsi kecocokan yang dibuat untuk mengukur tingkat kesesuaian suatu solusi terhadap kriteria yang ditentukan .

Tahap proses siklus genetika diawali dengan membangkitkan populasi awal yaitu pembangkitan sejumlah individu secara acak. Pada kasus penentuan komposisi bahan pangan untuk diet penyakit ginjal dan saluran kemih jumlah kromosom yang dibangkitkan sebanyak 20 kromosom [3]. Pada optimasi pengantaran barang dalam perdagangan online dibangkitkan dalam satu populasi sebanyak 8 kromosom dengan panjang kromosom sebanyak 40 gen [2]. Kemudian evaluasi nilai kecocokan yang dilakukan dengan perhitungan menggunakan fungsi kecocokan yang telah dibuat.

Proses seleksi memegang peranan penting dalam Algoritma Genetika. Proses seleksi digunakan agar hanya kromosom-kromosom terbaik yang dapat melanjutnya dalam proses algoritma Genetika berikutnya. Pada kasus penempatan guru sekolah dasar di kecamatan Cikajang teknik seleksinya menggunakan teknik Rank Based Fitness yaitu proses perankingan yang digunakan dengan memilih nilai pelanggaran paling kecil sehingga hasil proses seleksi merupakan empat kromosom yang mempunyai ranking terbaik [7].

Perancangan jaringan akses serat optik fiber to the home proses seleksinya menggunakan metode Tournament Selection, dalam Tournament Selection individu terbaik dipilih dengan memasukkan individu- individu kedalam mating pool. Selanjutnya turnamen akan terus berlulang sampai seluruh mating pool terisi dan menghasilkan individu terbaik [8]. Beberapa teknik lainnya yaitu Roulette Wheel proses seleksi berdasarkan kualitas individual, memastikan agar individu atau node dengan fitness atau fungsi objektif yang lebih baik akan memiliki peluang lebih besar untuk dipilih. Seleksi pada optimasi distribusi barang dua menggunakan teknik Elitism bekerja dengan mengumpulkan semua offspring dan parent dalam satu 
penampungan, popsize dengan fitness individu terbaik akan lolos menjadi generasi selanjutnya [9].

Kromosom-kromosom yang terpilih pada proses seleksi menjadi induk untuk disilangkan. Persilangan digunakan untuk membentuk individu baru. Ada beberapa proses persilangan yang dapat digunakan di antaranya pada optimalisasi rute obyek wisata di Bandung Raya menggunakan teknik persilangan Partially Mapped Crossover (PMX) atau dikenal juga dengan permutasi crossover, Cara persilangan dengan persilangan permutasi adalah dengn terlebih dahulu menentukan dua posisi yaitu batas kiri dan batas kanan dengan aturan secara acak sesuai panjang kromosom yaitu 30, gen pada dua kromosom yang berada pada dua posisi batas kiri dan batas kanan ditukar diantara kromosom, kemudian gen yang berada pada dua posisi batas kiri dan kanan digunakan untuk menentukan hubungan mapping yang kemudian digunakan untuk menentukan kromosom keturunan yang mengacu pada hubungan mapping, hal ini bertujuan untuk dapat mencegah adanya gen ganda pada suatu kromosom [10],

Penyusunan box komponen program spirit di dalam kontainer menggunakan order crossover pertukaran kromosom antara individu orang tua tetapi urutan gen dalam kromosom tetap dijaga, untuk menghasilkan anak melalui mekanisme random akan dilakukan proses rekombinasi antara individu empat dan 10 sebagai induk 1 dan induk [11]. Optimasi persediaan barang dalam produksi jilbab menggunakan metode one-cut-point yaitu dilakukan dengan memilih dua induk secara acak dari populasi kemudian memilih satu titik potong dan menukarkan bagian kanan dari tiap induk untuk menghasilkan offspring [12].

Mutasi merupakan tahap perubahan nilai gen dari sebuah kromosom. Tiap kromosom akan memiliki nilai probabilitas untuk mengalami proses mutasi. Pada kasus penentuan rute obyek wisata di Bandung Raya menggunakan teknik inversion mutation, dengan terlebih menentukan dua posisi yaitu batas kiri dan batas kanan dengan aturan secara acak sesuai dengan panjang kromosom yaitu 30, gen yang ada pada dua posisi ini yaitu batas kiri dan batas kanan di tukar, gen yang ada pada batas kiri menjadi gen yang berada pada batas kanan akhir [10]. Gambar 1 mutasi teknik inversion mutation.

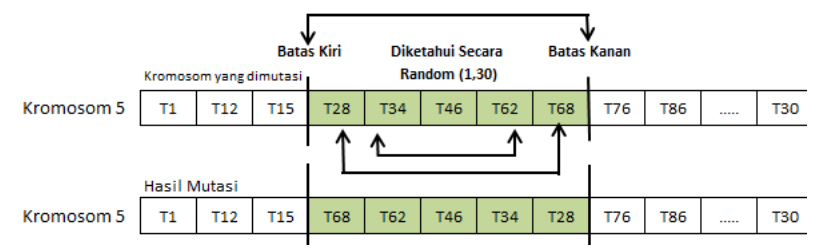

Gambar 1. Mutasi teknik inversion mutation

Siklus genetika akan berhenti ketika sudah memenuhi kriteria penghentian. Terdapat tiga kriteria penghentian generasi, yaitu batas maksimum generasi, fungsi kecocokan bernilai paling kecil atau paling besar tergantung pada permasalahannya, dan kondisi ketika fungsi kecocokan berturut-turut tidak berubah atau konvergen seteleh beberapa generasi. Pada pengantaran barang dalan perdagangan online penghentian generasi setelah fungsi kecocokannya berturut-turut tidak mengalami perubahan atau tetap pada 50 generasi dan mencapai nilai maksimal 1000 generasi [2].

\section{METODE}

Algoritma Genetika merupakan metode pencarian solusi yang sesuai dengan kriteria pada ruang pencarian yang luas dan komplek. Algoritma Genetika telah mengalami pengembangan bebarapa diantaranya algoritma Genetika Ganda yang telah berhasil digunakan untuk menyelesaikan Capacitated vehicle routing problem (CVRP) dengan cara yang berbeda dari algoritma genetika biasa, algoritma genetika ganda akan terlebih dahulu mendekomposisi masalah menjadi beberapa daerah yang independen [13]. Algoritma genetika ganda menghasilkan kinerja yang baik pada permasalahan yang membutuhkan proses dekomposisi. Algoritma genetika Non-dominated Sorting Genetic Algorithm II (NSGA) adalah algoritma genetika yang sangat populer untuk digunakan pada masalah optimisasi multiobjek. Jadi masalah optimasi multiobjective adalah masalah yang melibatkan lebih dari satu fungsi objektif yang harus diminimalkan atau dimaksimalkan. NSGA adalah algoritma yang sangat efektif tetapi banyak dikritik karena kompleksitas perhitungan, kurangnya elitisme dan memerlukan parameter yang optimal, algoritma genetika NSGA-II dapat memberikan solusi optimal dan dapat mempercepat proses pencarian solusi pada optimasi dalam distribusi kapal perang di wilayah perairan Indonesia [14]. Algoritma genetika NSGA sangat efektif digunakan pada permasalah optimasi multiobjek.

Penelitian ini membangun model komputasi optimalisasi jumlah tiket yang dilakukan pada 10 sub-kelas dengan sembilan rute dengan kemungkinan kombinasi solusi yang sangat banyak (90) ${ }^{100}$ dan hanya melibatkan satu fungsi objektif yaitu memaksimalkan keuntungan dan tidak perlu dilakukan proses dekomposisi berdasarkan hal tersebut algoritma genetika biasa adalah metode yang paling cocok karena algoritma genetika dapat melakukan proses pencarian solusi pada ruang pencarian yang luas dan komplek tanpa harus mencoba setiap kemungkinan.

Sistem optimalisasi distribusi jumlah tiket pesawat seperti yang diperlihatkan Gambar 2, terdiri dari empat bagian yaitu input, pra proses, proses dan output. input pada sistem ini kriteria berupa kapasitas seat yang ditentukan oleh maskapai penerbangan yaitu 150 seat, 250 seat dan 300 seat. Kapasitas seat tersebut merupakan constraint yang digunakan untuk mengatur jumlah tiket pada setiap 10 gen. Kombinasi jumlah tiket yang dihasilkan secara acak pada 10 gen tidak boleh melebihi kapasitas seat yang telah ditentukan.

Selanjutnya adalah tahap Pra-proses yang terdiri dari tahap pengkodean isi gen berupa diskrit angka 1-100, representasi kromosom dan fungsi kecocokan berdasarkan 
rasio untuk setiap sub-kelas untuk mendapatkan kombinasi jumlah tiket yang optimal.

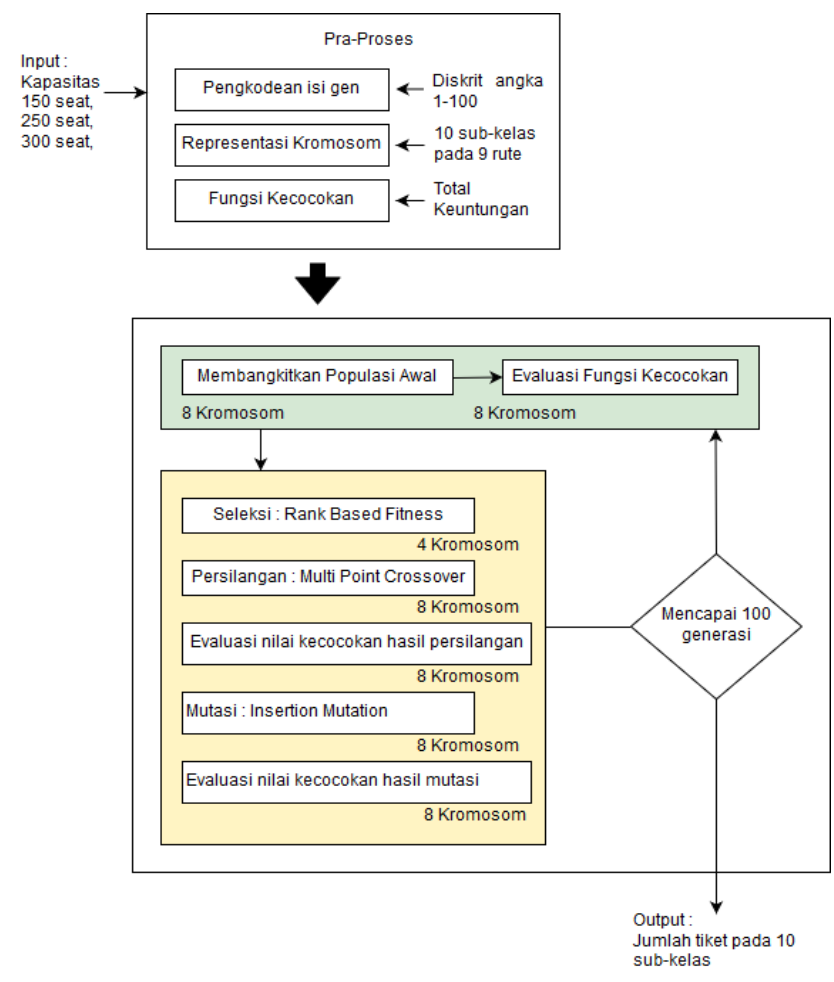

Gambar 2. Sistem optimalisasi distribusi jumlah tiket

\section{A. Representasi Struktur Kromosom}

Pada penelitian ini kromosom merepresentasikan jumlah 10 sub-kelas dalam 9 rute penerbangan, sehingga jumlah gen dalam satu kromosom sebanyak 90 gen, isi gen berupa diskrit angka dari 1-100 sehingga menghasilkan (90) ${ }^{100}$ kombinasi solusi. Struktur kromosom untuk distribusi jumlah tiket diperlihatkan pada Gambar 3.

Panjang setiap 10 gen menyatakan sub-kelas. Panjang setiap 30 gen menyatakan 30 kode sub-kelas pada tiga rute penerbangan, serta panjang 90 gen nyatakan 90 kode subkelas pada 9 rute penerbangan dengan tiga jenis kepadatan yang berbeda yaitu rute padat, rute sedang dan rute sepi.

\section{B. Pembangkitan Populasi Awal}

Pembangkitan populasi awal merupakan tahapan pertama dari siklus genetika, populasi awal diambil dari beberapa kromosom yang dimasukan ke dalam satu populasi dalam setiap generasi. Rangkai kromosom tersebut memiliki isi yang berbeda berupa nilai yang diambil secara acak. Pada penelitian ini populasi awal yang dibangkitkan sebanyak delapan kromosom dengan panjang gen 90. Gambar 5 Membangkitkan populasi awal.

\section{Membangun Fungsi Kecocokan}

Fungsi kecocokan digunakan untuk mencari jumlah tiket pada setiap gen yang terdapat pada kromosom dan kriteria yang digunakan untuk mencari total pendapatan yang paling besar setelah dikurangin dengan jumlah biaya operasional. Kriteria tersebut kemudian dijadikan fungsi matematika sebagai fungsi kecocokan dan gen tersebut merupakan representasi dari jumlah tiket. Persamaan 1 Fungsi kecocokan distribusi jumlah tiket.

$$
F(X)=B E P-\left(\sum_{i=1}^{90} g_{(i)} *\left(\sum_{j=1}^{90} \operatorname{Harga}_{(j)}\right)\right)
$$

keterangan :

$F \quad$ : menyatakan fungsi kecocokan

BEP : menyatakan jumlah biaya operasional

$g \quad$ : menyatakan gen

Harga : menyatakan Harga tiket

Distribusi jumlah tiket setiap sub-kelas dilakukan pada sembilan rute dengan tiga jenis kepadatan yang berbeda yaitu rute padat, rute sedang dan rute sepi. Kode sub-kelas menyatakan tingkatan harga. Merujuk pada persamaan 1 jumlah tiket dikali dengan harga tiket pada sub-kelas maka dibutuhkan data harga tiket untuk setiap sub-kelas pada sembilan rute. Harga tiket yang digunakan pada sub-kelas setiap rute berbeda karena perbedaan jarak dan durasi penerbangan. Tabel I Harga tiket sub-kelas pada rute padat, Tabel II Harga tiket sub-kelas pada rute sedang, Tabel III Harga tiket sub-kelas pada rute sepi.

TABEL I

HARGA TIKET SUB-KELAS PADA RUTE PADAT

\begin{tabular}{|c|c|c|c|}
\hline $\begin{array}{c}\text { Kode } \\
\text { Sub-kelas }\end{array}$ & $\begin{array}{c}\text { Jakarta- } \\
\text { Makasar }\end{array}$ & $\begin{array}{c}\text { Jakarta- } \\
\text { Bali }\end{array}$ & $\begin{array}{c}\text { Jakarta- } \\
\text { Surabaya }\end{array}$ \\
\hline Y & Rp. 2.284.000 & Rp. 1.799.000 & Rp. 1.634.000 \\
\hline N & Rp. 2.106.355 & Rp. 1.659.077 & Rp. 1.506.911 \\
\hline K & Rp. 1.928.711 & Rp. 1.519.155 & Rp. 1.379.822 \\
\hline M & Rp. 1.751.066 & Rp. 1.379.233 & Rp. 1.252.733 \\
\hline B & Rp. 1.573.422 & Rp. 1.239.311 & Rp. 1.125.644 \\
\hline S & Rp. 1.395.777 & Rp. 1.099.388 & Rp. 998.555 \\
\hline V & Rp. 1.218.133 & Rp. 959.466 & Rp. 871.466 \\
\hline T & Rp. 1.040.488 & Rp. 819.544 & Rp. 744.377 \\
\hline Q & Rp. 862.844 & Rp. 679.622 & Rp. 617.288 \\
\hline L & Rp. 685.200 & Rp. 539.700 & Rp. 490.200 \\
\hline
\end{tabular}

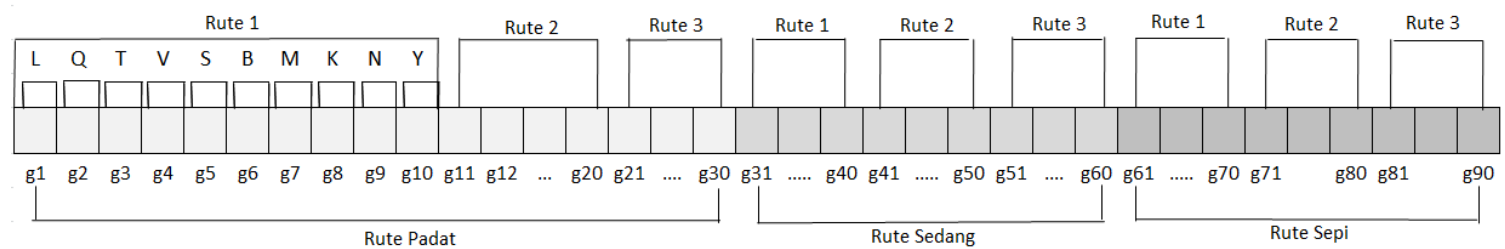

Gambar 3. Struktur kromosom distribusi jumlah tiket 
TABEL II

HARGA TIKET SUB-KELAS PADA RUTE SEDANG

\begin{tabular}{|c|c|c|c|}
\hline $\begin{array}{c}\text { Kode } \\
\text { Sub- Kelas }\end{array}$ & $\begin{array}{c}\text { Jakarta- } \\
\text { Lombok }\end{array}$ & $\begin{array}{c}\text { Jakarta- } \\
\text { Malang }\end{array}$ & $\begin{array}{c}\text { Jakarta- } \\
\text { Solo }\end{array}$ \\
\hline Y & Rp. 1.798.000 & Rp. 1.636.000 & Rp. 1.258.000 \\
\hline N & Rp. 1.658.155 & Rp. 1.508.755 & Rp. 1.160.155 \\
\hline K & Rp. 1.518.311 & Rp. 1.381.511 & Rp. 1.062.311 \\
\hline M & Rp. 1.378.466 & Rp. 1.254.266 & Rp. 964.466 \\
\hline B & Rp. 1.238.622 & Rp. 1.127.022 & Rp. 866.622 \\
\hline S & Rp. 1.098.777 & Rp. 999.777 & Rp. 768.777 \\
\hline V & Rp. 958.933 & Rp. 872.533 & Rp. 670.933 \\
\hline T & Rp. 819.088 & Rp. 745.288 & Rp. 573.088 \\
\hline Q & Rp. 679.244 & Rp. 618.044 & Rp. 475.244 \\
\hline L & Rp. 539.400 & Rp. 490.800 & Rp. 377.400 \\
\hline
\end{tabular}

TABEL III

HARGA TIKET SUB-KELAS PADA RUTE SEPI

\begin{tabular}{|c|c|c|c|}
\hline $\begin{array}{c}\text { Kode } \\
\text { Sub-kelas }\end{array}$ & $\begin{array}{c}\text { Jakarta- } \\
\text { Yogyakarta }\end{array}$ & $\begin{array}{c}\text { Denpasar- } \\
\text { Surabaya }\end{array}$ & $\begin{array}{c}\text { Bandung- } \\
\text { Medan }\end{array}$ \\
\hline Y & Rp. 1.171.000 & Rp. 905.000 & Rp. 2.287.000 \\
\hline N & Rp. 1.079.922 & Rp. 834.611 & Rp. 2.109.122 \\
\hline K & Rp. 988.844 & Rp. 764.222 & Rp. 1.931.244 \\
\hline M & Rp. 897.766 & Rp. 693.833 & Rp. 1.753.366 \\
\hline B & Rp. 806.688 & Rp. 623.444 & Rp. 1.575.488 \\
\hline S & Rp. 715.611 & Rp. 553.055 & Rp. 1.397.611 \\
\hline V & Rp. 624.533 & Rp. 482.666 & Rp. 1.219.733 \\
\hline T & Rp. 533.455 & Rp. 412.277 & Rp. 1.041.855 \\
\hline Q & Rp. 442.377 & Rp. 341.888 & Rp. 863.977 \\
\hline L & Rp. 351.300 & Rp. 271.500 & Rp. 686.100 \\
\hline
\end{tabular}

\section{Seleksi}

Proses seleksi adalah proses untuk memperoleh kromosom terbaik yang akan dipertahankan untuk dijadikan populasi pada generasi berikutnya. Pada penelitian ini, teknik seleksi yang digunakan adalah Rank Based Fitnes dimana nilai fitness tertinggi akan berada pada rank pertama. 4 kromosom terbesar akan dipilih untuk dilakukan proses persilangan. Tabel IV Hasil operator seleksi.

TABEL IV

HASIL SELEKSI

\begin{tabular}{|c|c|}
\hline $\begin{array}{c}\text { Kromosom } \\
\text { yang dibangkitkan }\end{array}$ & $\begin{array}{c}\text { Nilai } \\
\text { Kecocokan }\end{array}$ \\
\hline Kromosom ke-1 & $418,401,200.00$ \\
\hline Kromosom ke-3 & $395,371,100.00$ \\
\hline Kromosom ke-5 & $382,434,000.00$ \\
\hline Kromosom ke-8 & $360,679,200.00$ \\
\hline
\end{tabular}

\section{E. Persilangan}

Persilangan dilakukan untuk menghasilkan generasi baru dari kromosom induk yang telah terpilih sebelumnya. Teknik persilangan yang digunakan pada penelitian ini adalah Multi Point Crossover, karena panjang gen pada satu kromosom adalah 90 gen sehingga dibutuhkan teknik persilangan yang dilakukan pada beberapa titik dengan

Kromosom Sebelum disilangkan

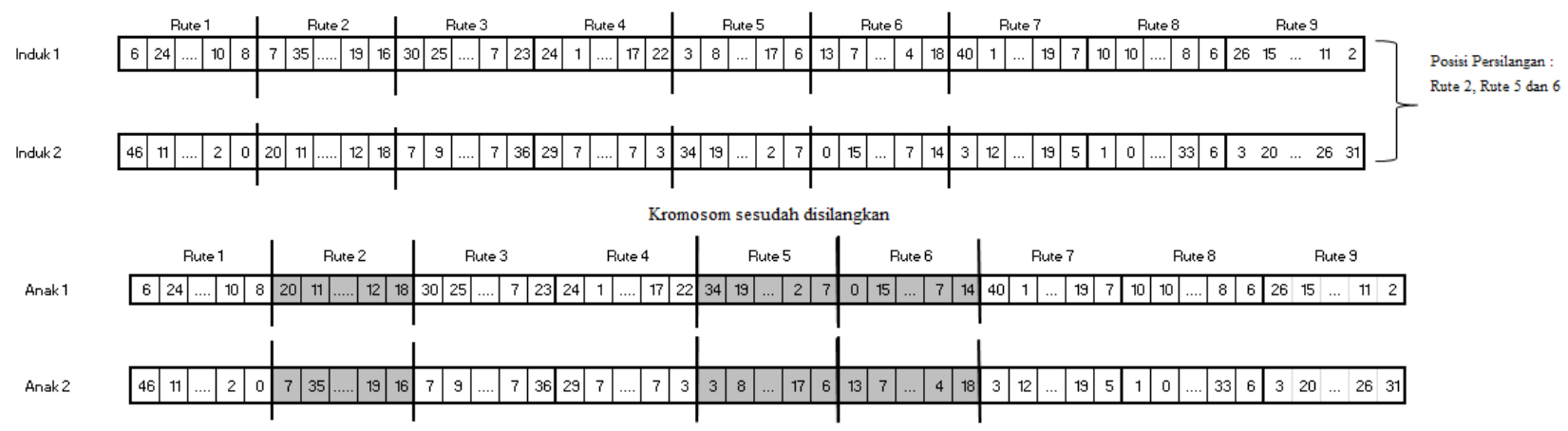

: Gen yang disilangkan

Gambar 4. Proses persilangan

Kromosom

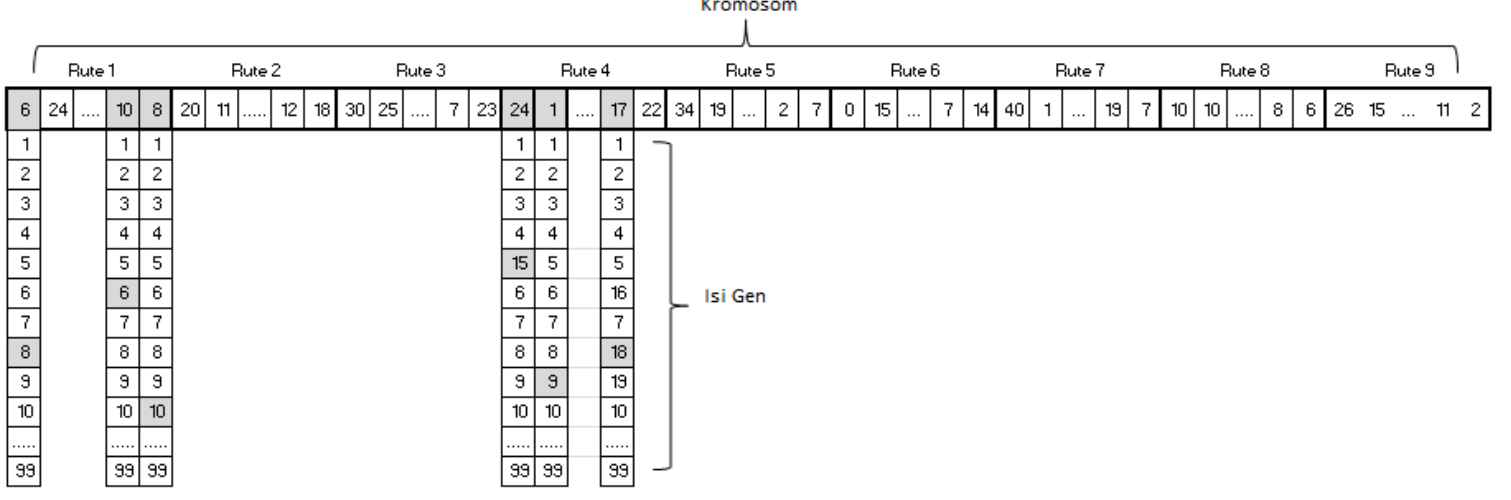

Gambar 5. Proses Mutasi 
segmen yang sama. Gambar 4 Proses persilangan.

Proses persilangan dengan menggunakan metode Multi-

Point Crossover dilakukan dengan cara sebagai berikut.

1. Pilih empat induk dari kromosom terbaik hasil seleksi.

2. Silangkan induk pertama dengan induk ketiga dan induk kedua dengan keempat.

3. Tentukan jumlah titik persilangan sebanyak 3 titik dengan titik persilangan yang telah dipilih secara acak dengan kelipatan 10.

4. Silangkan dengan panjang 10 gen.

\section{F. Mutasi}

Mutasi merupakan tahap perubahan nilai gen dari sebuah kromosom. Mutasi diterapkan dengan probabilitas yang sangat kecil. Proses mutasi dikatakan berhasil jika menghasilkan nilai fitness yang lebih baik, maka individu hasil mutasi akan menggantikan individu lama.

Teknik mutasi yang digunakan adalah Insertion Mutation, karena teknik ini gen yang dimutasikan dirubah sesuai daftar gen yang dilakukan secara acak pada segmen tertentu tanpa memperhitungkan gen yang lainnya. Gambar 5 Proses mutasi. Proses mutasi dengan menggunakan metode Insertion Mutation dilakukan dengan cara sebagai berikut.

1. Acak rute pada kromosom (1-9)

2. Tiga Rute yang terpilih, setiap rute acak subclass (110)

3. Tiga subclass yang terpilih dijumlahkan disimpan pada variable rest

4. Acak nilai subclass dari 0 sampai 50 untuk mendapatkan nilai yang memiliki jumlah yang sama, simpan pada variable newValue

5. Tukarkan Isi gen subclass yang disimpan pada variable rest dengan isi gen yang disimpan pada variable newValue

\section{G. Penghentian Generasi}

Penghentian generasi digunakan untuk menyatakan berhentinya proses dalam algoritma genetika. Pada penelitian ini penghentian generasi dilakukan yaitu jika telah mencapai batas maksimum 100 generasi dan menghasilkan nilai kecocokan yang tidak berubah atau konvergen. Apabila salah satu kondisi penghentian generasi terpenuhi, maka kromosom tersebut dinyatakan sebagai kromosom yang dipilih sebagai solusi optimal.

\section{HASIL DAN DISKUSI}

Pengujian sistem dilakukan terhadap dua metode mutasi. Pengujian pertama menggunakan metode mutasi tiga kode sub-kelas pada empat rute pada kapasitas 150 seat, sedangkan pengujian kedua menggunakan metode mutasi tiga kode sub-kelas pada delapan rute kapasitas 150 seat. Masing-masing pengujian dilakukan sebanyak delapan kali dengan maksimum 100 generasi.
Hasil pengujian dengan metode mutasi tiga kode subkelas pada empat rute yang diperlihatkan pada Tabel V, sedangkan untuk pengujian dengan metode mutasi tiga kode sub-kelas pada delapan rute diperlihatkan pada Tabel VI.

Pada pengujian metode mutasi 3 sub-kelas pada 4 rute. Pada proses mutasi ini, 3 gen yang terpilih dijumlahkan dan dimutasi dengan 3 angka yang terpilih secara acak, gen yang terpilih harus memiliki jumlah yang sama. Pada pengujian dengan metode mutasi pada empat rute terlihat bahwa nilai kecocokan mengalami peningkatan pada beberapa generasi generasi. Keuntungan tertinggi terdapat pada pengujian kelima, dengan kenaikan keuntungan seperti yang terlihat pada Gambar 6. Peningkatan jumlah keuntungan yang cukup banyak terjadi pada iterasi pertama sampe iterasi ke50. Tetapi pada iterasi ke-60 sampe ke-100 nilai kecocokan bernilai tetap atau konvergen.

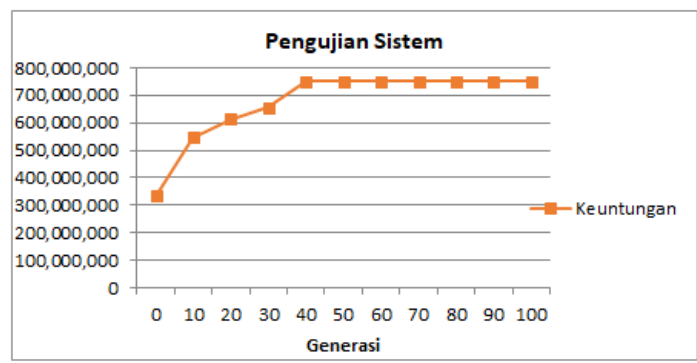

Gambar 6. Grafik pengujian sistem mutasi 4 rute

Keuntungan tertinggi dari delapan kali pengujian terdapat pada pengujian kelima dan menghasilkan solusi berupa jumlah tiket yang terpilih pada 10 sub-kelas dengan 9 rute. Tabel VII Jumlah tiket hasil pengujian 4 rute.

TABEL VII

JUMLAH TIKET TERDISTRIBUSI HASIL PENGUJIAN MUTASI 4 RUTE

\begin{tabular}{|c|c|c|c|c|c|c|c|c|c|}
\hline $\begin{array}{c}\text { Kode } \\
\text { Sub- } \\
\text { kelas }\end{array}$ & JM & JB & JS & JL & JO & JA & JY & DS & BM \\
\hline Y & 43 & 43 & 43 & 43 & 43 & 43 & 43 & 43 & 43 \\
\hline N & 30 & 30 & 30 & 30 & 30 & 30 & 30 & 30 & 30 \\
\hline K & 10 & 10 & 10 & 10 & 10 & 10 & 10 & 10 & 10 \\
\hline M & 36 & 36 & 36 & 36 & 36 & 36 & 36 & 36 & 36 \\
\hline B & 2 & 2 & 2 & 2 & 2 & 2 & 2 & 2 & 2 \\
\hline S & 14 & 14 & 14 & 14 & 14 & 14 & 14 & 14 & 14 \\
\hline V & 6 & 6 & 6 & 6 & 6 & 6 & 6 & 6 & 6 \\
\hline T & 0 & 0 & 0 & 0 & 0 & 0 & 0 & 0 & 0 \\
\hline Q & 7 & 7 & 7 & 7 & 7 & 7 & 7 & 7 & 7 \\
\hline L & 2 & 2 & 2 & 2 & 2 & 2 & 2 & 2 & 2 \\
\hline
\end{tabular}

Keterangan :

JM : Jakarta-Makasar

JB : Jakarta-Bali

JS : Jakarta-Surabaya

JL : Jakarta-Lombok

JA : Jakarta-Malang

JO : Jakarta-Solo

JY : Jakarta-Yogyakarta

DS : Denpasar-Surabaya 
BM : Bandung-Medan

Nilai kecocokan evolusi awal yang paling tinggi menggunakan metode mutasi empat rute terdapat pada pengujian ketiga dan ketujuh, yaitu Rp. 439.807.600 dan Rp. 412.656.000. berbeda dengan nilai kecocokan evolusi awal menggunakan metode mutasi delapan rute, nilai kecocokan yang dihasilkan lebih kecil yaitu terdapat pada pengujian ketiga sebesar Rp. 401.793.300 dan pengujian kedelapan sebesar Rp. 419.857.100.
Nilai kecocokan pada populasi awal selalu berbeda pada setiap pengujian yang disebabkan oleh proses pembangkitan populasi awal secara acak. Pengujian dengan menggunakan metode mutasi empat delapan rute, yang menghasilkan nilai kecocokan tersebesar yaitu Rp. 763.265.300 pada pengujian kelima dengan menggunakan metode mutasi tiga kode subkelas pada delapan rute dan dengan kenaikan keuntungan seperti yang terlihat pada Gambar 7.

TABEL V

HASIL PENGUJIAN SISTEM DENGAN METODE MUTASI TIGA KODE SUB-KELAS PADA EMPAT RUTE

\begin{tabular}{|c|c|c|c|c|c|c|c|c|}
\hline \multirow{2}{*}{$\begin{array}{l}\text { ITERASI } \\
\text { KE }\end{array}$} & \multicolumn{8}{|c|}{ TOTAL KEUNTUNGAN DARI PENGUJIAN KE } \\
\hline & 1 & 2 & 3 & 4 & 5 & 6 & 7 & 8 \\
\hline 0 & 373.569 .600 & 256.837.300 & 439.807 .600 & 329.245 .000 & 333.103 .300 & 329.694 .600 & 412.656 .000 & 356.637 .500 \\
\hline 10 & 543.638 .500 & 506.816 .300 & 611.745 .000 & 468.577 .400 & 547.588 .000 & 591.819 .000 & 501.927 .400 & 512.515 .700 \\
\hline 20 & 592.884 .000 & 533.294 .300 & 655.800 .200 & 595.005 .900 & 614.516 .200 & 607.212 .000 & 551.840 .500 & 571.203 .600 \\
\hline 30 & 650.213 .000 & 594.695 .400 & 667.800 .201 & 673.494 .200 & 655.570 .200 & 637.743 .700 & 589.014 .400 & 619.433 .300 \\
\hline 40 & 678.464 .000 & 617.406 .400 & 670.800 .202 & 731.505 .200 & 750.752 .200 & 645.559 .300 & 633.023 .100 & 653.852 .300 \\
\hline 50 & 678.464 .000 & 644.171 .400 & 692.194 .200 & 741.597 .200 & 750.752 .200 & 664.214 .000 & 653.353 .100 & 683.620 .300 \\
\hline 60 & 678.464 .000 & 662.891 .400 & 692.194 .200 & 741.597 .200 & 750.752 .200 & 665.136 .000 & 662.283 .100 & 683.620 .300 \\
\hline 70 & 678.464 .000 & 662.891 .400 & 692.194 .200 & 741.597 .200 & 750.752 .200 & 668.130 .000 & 662.283 .100 & 683.620 .300 \\
\hline 80 & 678.464 .000 & 662.891 .400 & 692.194 .200 & 741.597 .200 & 750.752 .200 & 668.130 .000 & 662.283 .100 & 683.620 .300 \\
\hline 90 & 678.464 .000 & 662.891 .400 & 692.194 .200 & 741.597 .200 & 750.752 .200 & 668.130 .000 & 662.283 .100 & 683.620 .300 \\
\hline 100 & 678.464 .000 & 662.891 .400 & 692.194 .200 & 741.597 .200 & 750.752 .200 & 668.130 .000 & 662.283 .100 & 683.620 .300 \\
\hline Rata-rata & 628.141.192 & 587.970 .737 & 654.465 .309 & 658.855.537 & 673.276.645 & 619.445.327 & 604.839 .090 & 619.578 .563 \\
\hline
\end{tabular}

TABEL VI

HASIL PENGUJIAN SISTEM DENGAN METODE MUTASI TIGA KODE SUB-KELAS PADA DELAPAN RUTE

\begin{tabular}{|c|c|c|c|c|c|c|c|c|}
\hline \multirow{2}{*}{$\begin{array}{c}\text { Iterasi } \\
\text { Ke }\end{array}$} & \multicolumn{9}{|c|}{ Total Keuntungan Dari Pengujian Ke } \\
\cline { 2 - 9 } & 1 & 2 & 3 & 4 & 5 & 6 & 7 & 8 \\
\hline 0 & 392.843 .200 & 334.040 .200 & 401.793 .300 & 330.532 .500 & 242.890 .400 & 376.046 .300 & 308.325 .600 & 419.857 .100 \\
\hline 10 & 542.423 .400 & 471.971 .500 & 559.711 .700 & 487.004 .000 & 578.417 .300 & 476.229 .200 & 634.264 .100 & 481.346 .600 \\
\hline 20 & 613.445 .400 & 507.468 .200 & 623.801 .700 & 553.301 .000 & 604.897 .400 & 567.082 .300 & 706.853 .100 & 556.010 .100 \\
\hline 30 & 667.309 .400 & 514.741 .300 & 670.465 .700 & 592.594 .000 & 708.742 .300 & 691.859 .700 & 737.782 .100 & 618.583 .100 \\
\hline 40 & 700.501 .400 & 544.329 .200 & 688.482 .700 & 637.134 .000 & 763.265 .300 & 741.545 .200 & 759.891 .100 & 642.202 .100 \\
\hline 50 & 704.977 .400 & 546.276 .200 & 688.482 .700 & 710.271 .000 & 763.265 .300 & 741.545 .200 & 759.891 .100 & 650.867100 \\
\hline 60 & 715.111 .400 & 547.396 .200 & 688.482 .700 & 710.271 .000 & 763.265 .300 & 741.545 .200 & 759.891 .100 & 650.867 .100 \\
\hline 70 & 721.847 .400 & 547.396 .200 & 688.482 .700 & 710.271 .000 & 763.265 .300 & 741.545 .200 & 759.891 .100 & 650.867 .100 \\
\hline 80 & 721.847 .400 & 547.396 .200 & 688.482 .700 & 710.271 .000 & 763.265 .300 & 741.545 .200 & 759.891 .100 & 650.867 .100 \\
\hline 90 & 721.847 .400 & 547.396 .200 & 688.482 .700 & 710.271 .000 & 763.265 .300 & 741.545 .200 & 759.891 .100 & 650.867 .100 \\
\hline 100 & 721.847 .400 & 547.396 .200 & 688.482 .700 & 710.271 .000 & 763.265 .300 & 741.545 .200 & 759.891 .100 & 650.867 .100 \\
\hline $\begin{array}{c}\text { Rata- } \\
\text { rata }\end{array}$ & 683.115 .800 & 514.164 .327 & 643.195 .572 & 623.835 .591 & 679.800 .409 & 663.821 .263 & 700.587 .509 & 602.109 .236 \\
\hline
\end{tabular}




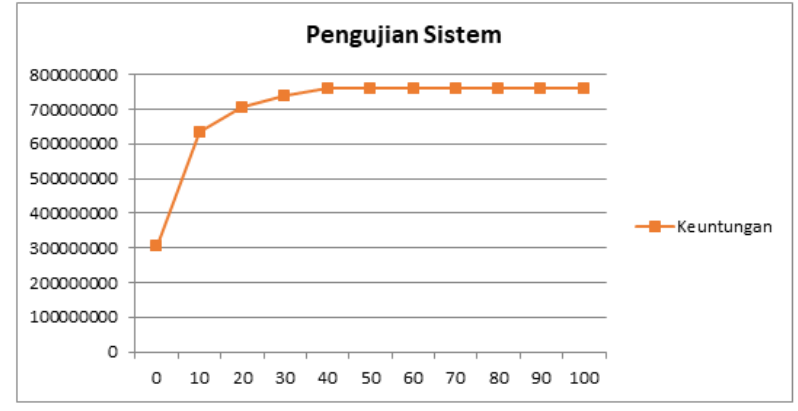

Gambar 7. Grafik pengujian sistem mutasi 8 rute

Pengujian dengan metode mutasi delapan rute yang dilakukan 8 kali menghasilkan nilai kecocokan tertinggi pada pengujian kelima dengan kromosom terpilih yang telah digambarkan dalam bentuk tabel seperti pada Tabel VII.

TABEL VIII

JUMLAH TIKET TERDISTRIBUSI HASIL PENGUJIAN MUTASI 8 RUTE

\begin{tabular}{|c|c|c|c|c|c|c|c|c|c|}
\hline $\begin{array}{c}\text { Kode } \\
\text { Sub- } \\
\text { kelas }\end{array}$ & JM & JB & JS & JL & JO & JA & JY & DS & BM \\
\hline Y & 23 & 23 & 23 & 23 & 23 & 23 & 23 & 23 & 23 \\
\hline N & 48 & 48 & 48 & 48 & 48 & 48 & 48 & 48 & 48 \\
\hline K & 34 & 34 & 34 & 34 & 34 & 34 & 34 & 34 & 34 \\
\hline M & 2 & 2 & 2 & 2 & 2 & 2 & 2 & 2 & 2 \\
\hline B & 26 & 26 & 26 & 26 & 26 & 26 & 26 & 26 & 26 \\
\hline S & 5 & 5 & 5 & 5 & 5 & 5 & 5 & 5 & 5 \\
\hline V & 6 & 6 & 6 & 6 & 6 & 6 & 6 & 6 & 6 \\
\hline T & 3 & 3 & 3 & 3 & 3 & 3 & 3 & 3 & 3 \\
\hline Q & 0 & 0 & 0 & 0 & 0 & 0 & 0 & 0 & 0 \\
\hline L & 3 & 3 & 3 & 3 & 3 & 3 & 3 & 3 & 3 \\
\hline
\end{tabular}

Implementasi antarmuka dari sistem optimalisasi distribusi harga tiket pesawat berdasarkan kepadatan rute yang sudah diimplementasikan pada perangkat lunak. Antarmuka halaman utama merupakan halaman awal dari sistem ketika pertama kali dijalankan. Terdapat beberapa menu pilihan diantaranya Kelola Data, Optimalisasi, Kombinasi, dan Informasi Sistem. Gambar 8 Halaman utama.

Antarmuka kelola data merupakan halaman untuk mengelola data harga tiket subclass pada sembilan rute. Menggambarkan pengguna dapat mengelola data harga tiket 10 sub-kelas pada 9 rute. Gambar 9 Halaman kelola data.

Antarmuka Optimalisasi merupakan halaman dari proses optimalisasi. Terdapat dua masukan berupa kapasitas seat dengan pilihan 150 seat, 250 seat dan 300 seat dengan maksimum generasi yaitu 100 generasi. Menggambarkan bahwa model komputasi dapat melakukan pra proses dengan memasukan jumlah seat yang telah ditentukan, maksimum generasi, serta melakukan proses siklus genetika mulai dari membangkitkan populasi awal, evaluasi nilai kecocokan, seleksi, persilangan, dan mutasi untuk mendapatkan hasil yang optimal. Gambar 10 halaman optimalisasi
Tahap proses optimalisasi sistem menampilkan populasi awal sebanyak 8 kromosom yang dilakukan secara acak. Gambar 11 hasil proses pembangkitan populasi awal. Kemudian sistem menampilkan hasil dari evaluasi nilai kecocokan. 8 kromosom yang dibangkitkan secara acak akan dilakukan proses seleksi untuk dijadikan induk kromosom di proses persilangan. Gambar 12 hasil proses seleksi. Proses persilangan menggunakan teknik multi-point crossover. Gambar 13 hasil proses persilangan. Gambar 14 hasil proses mutasi.

Antarmuka kombinasi merupakan halaman hasil dari proses algoritma genetika yang di konversi menjadi solusi optimal berupa total jumlah seat setiap subclass pada sembilan rute yang dikeluarkan dan keuntungan yang dihasilkan. Menggambarkan bahwa pengguna dapat melihat hasil dari proses optimalisasi yang telah dilakukan berupa list kombinas jumlah tiket dan total biaya yang dihasilkan. Gambar 15 representasi solusi dalam bentuk tabel hasil proses optimalisasi. 


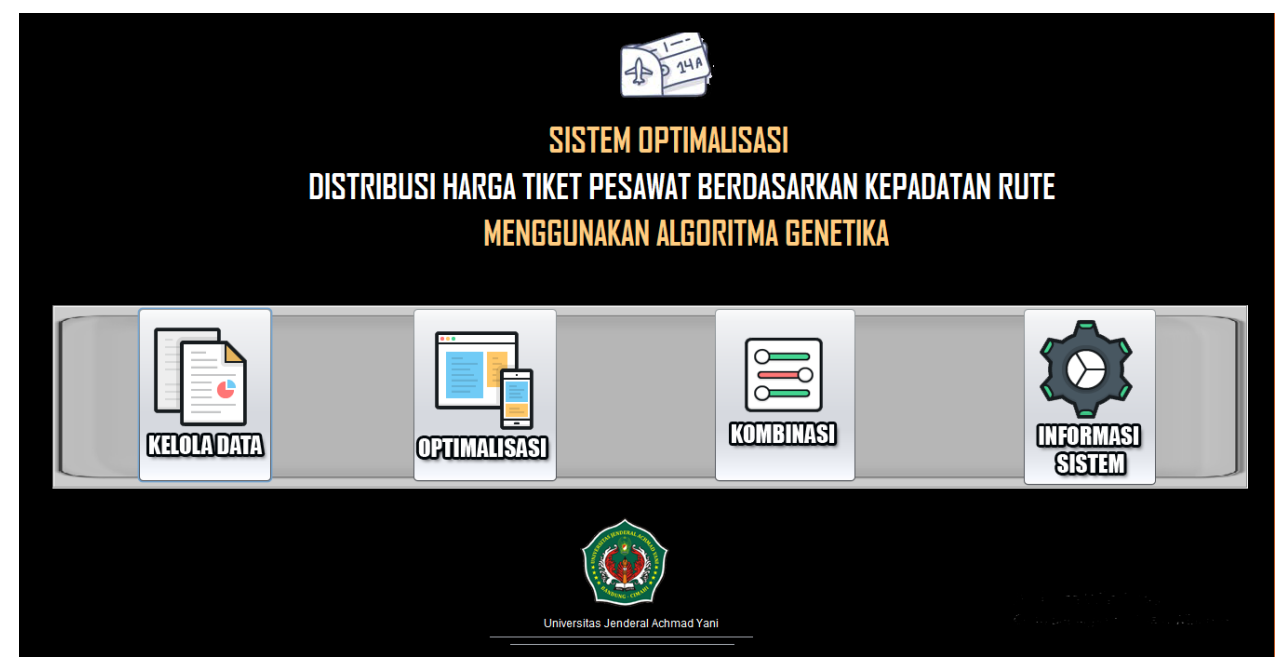

Gambar 8. Tampilan Awal

\section{를 KEIDLA DATA \\ DATA HARGA TIKET PESANAT PERSIIBCLLASS}

\section{(ब)}

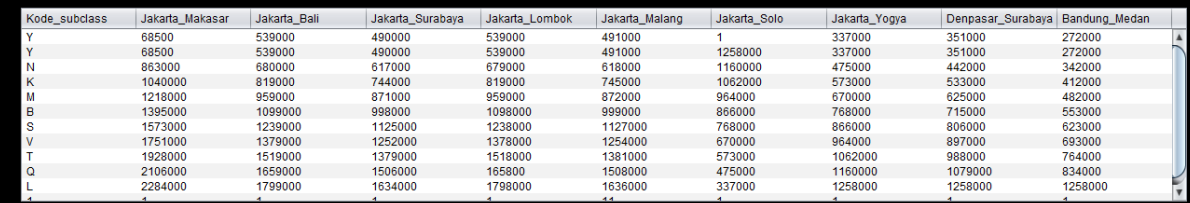

$\mathbb{4}$

Gambar 9. Halama Kelola Data Harga Tiket

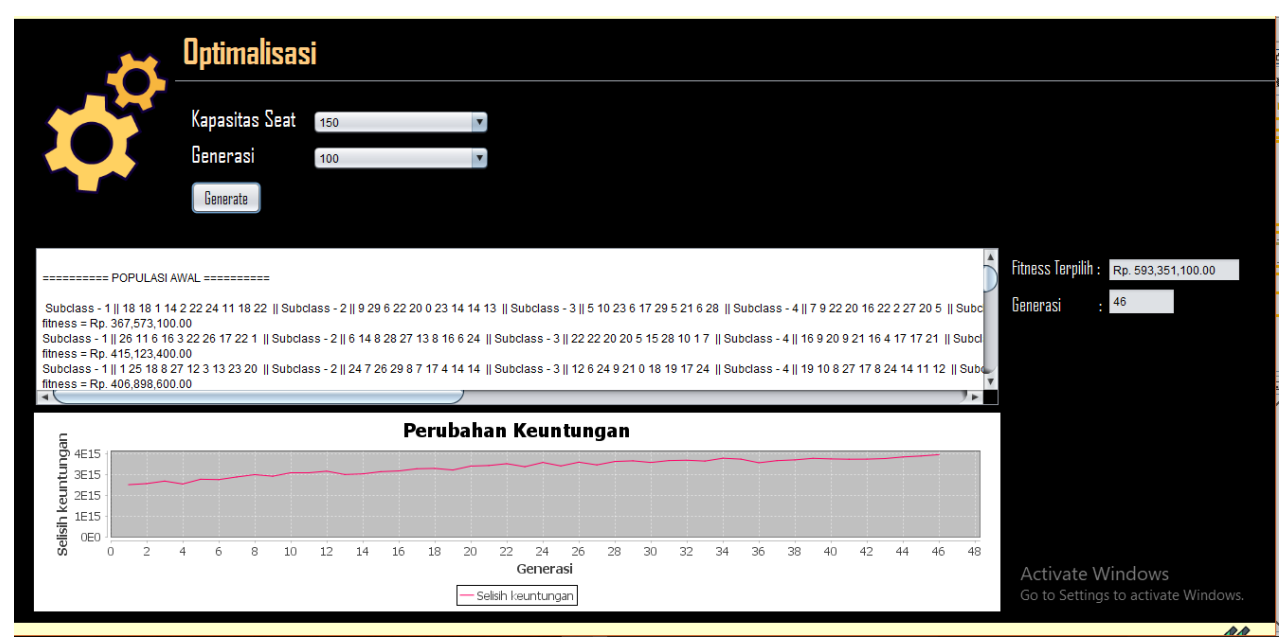

Gambar 10. Halaman Optimalisasi 


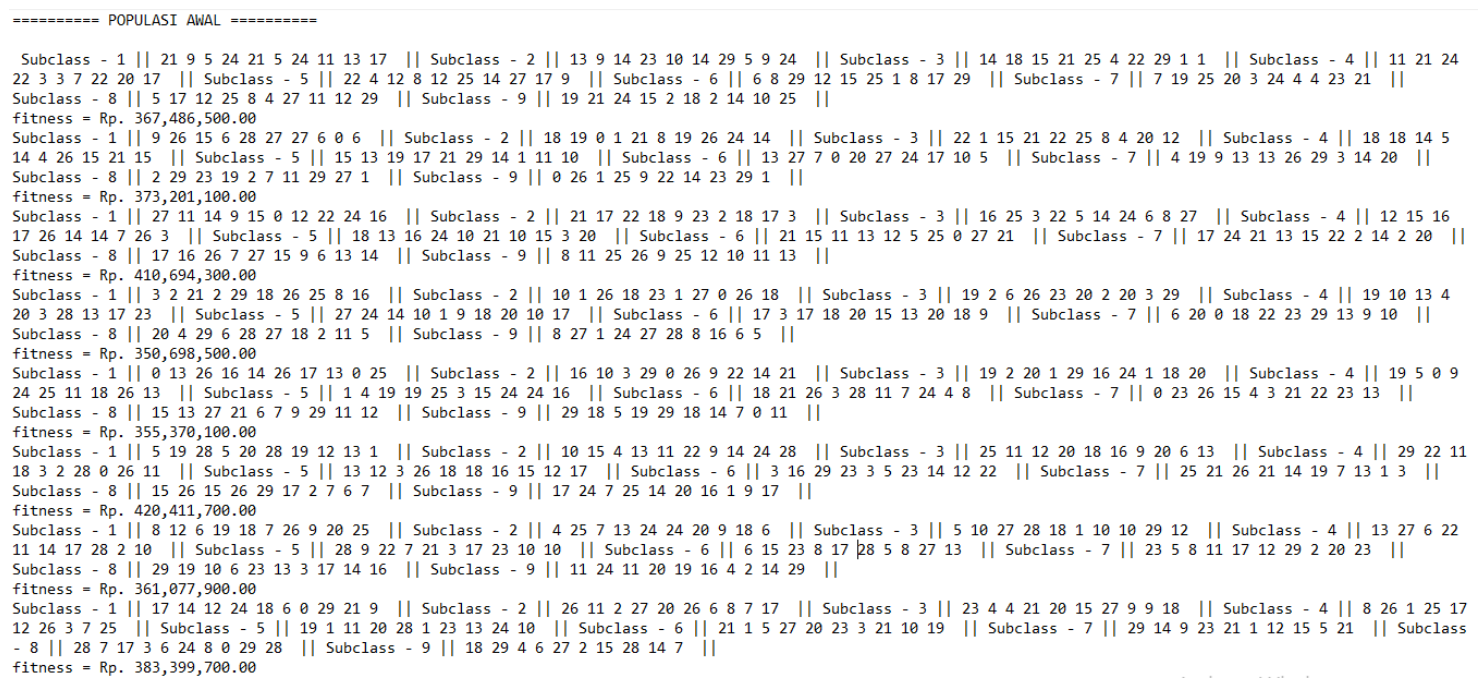

Gambar 11. Hasil Proses Pembangkitan Populasi Awal

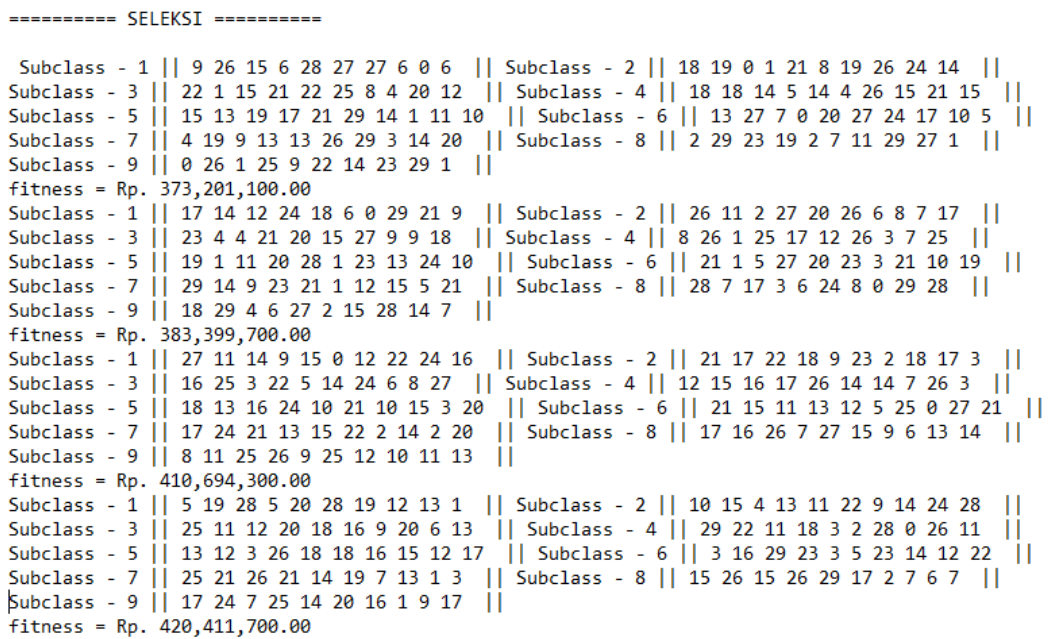

Gambar 12. Hasil Proses Seleksi

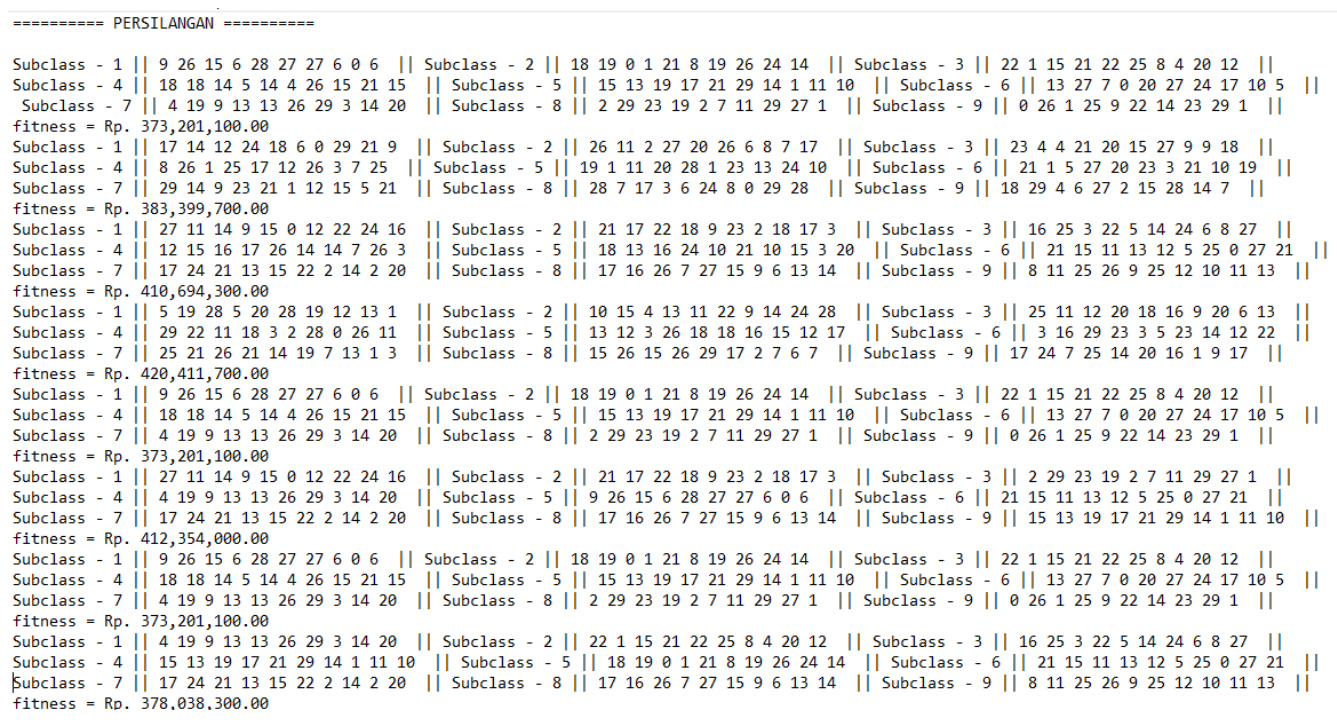

Gambar 13. Hasil Proses Persilangan 


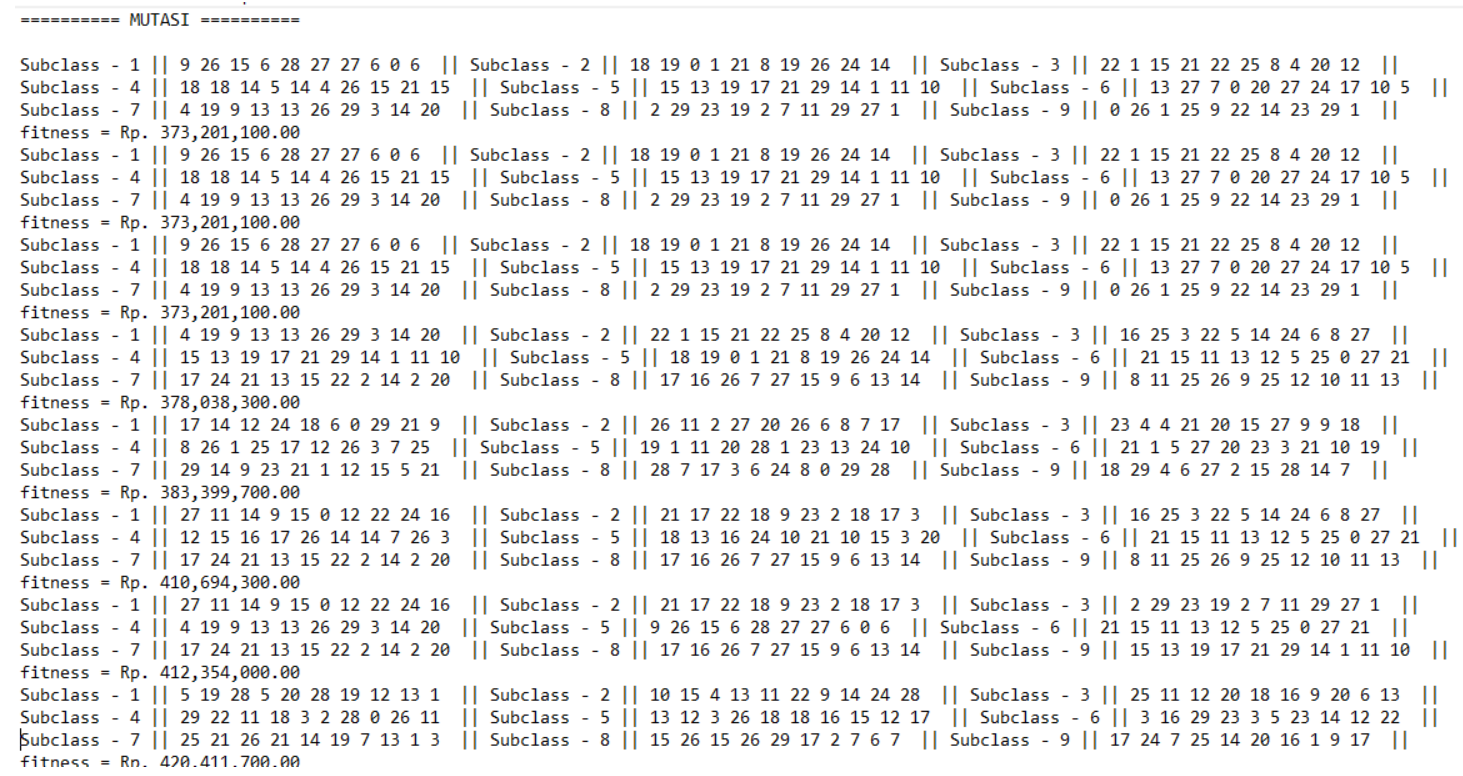

Gambar 14. Hasil Proses Mutasi

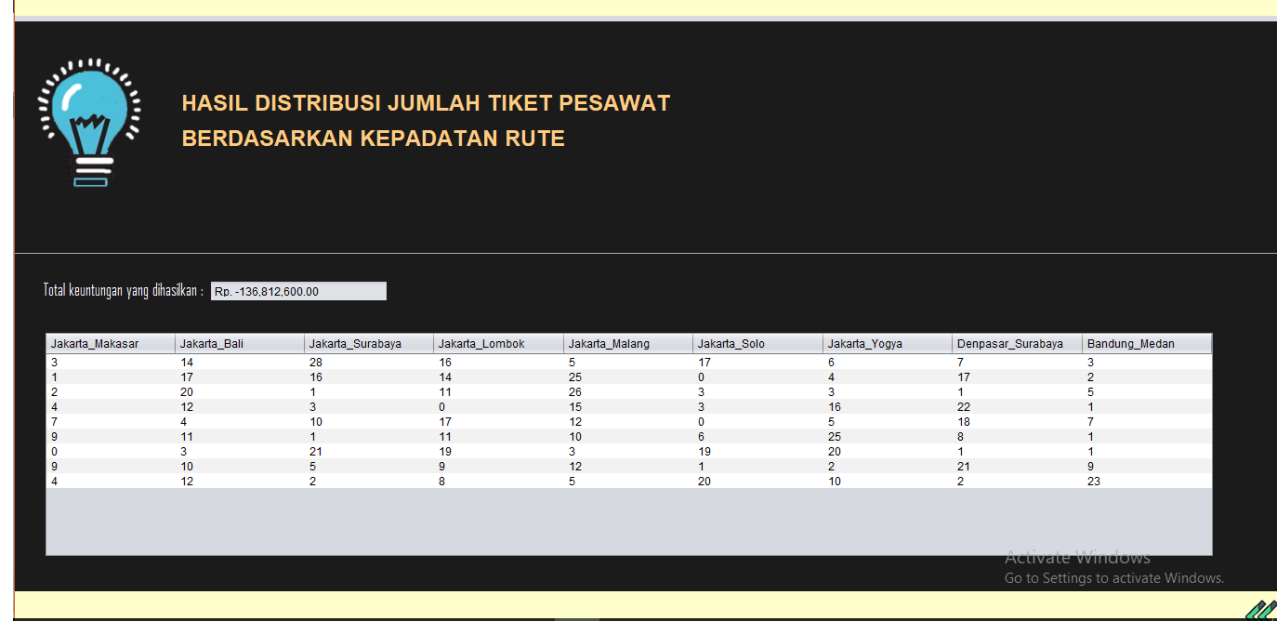

Gambar 15. Halaman Hasil Optimalisasi

\section{KESIMPULAN}

Penelitian ini telah menghasilkan sistem distribusi jumlah tiket pesawat berdasarkan kepadatan rute menggunakan Algoritma Genetika. Hasil dari penelitian ini adalah memberikan rekomendasi jumlah tiket pesawat pada subclass ekonomi yang terdistribusi. Sistem ini menggunakan atribut jumlah tiket yang terdistribusi pada 10 subclass harus sebanyak kapasitas seat yang ditetapkan yaitu 150 seat, 250 seat dan 300 seat.

Pada penelitian ini dilakukan pengujian sebanyak 100 evaluasi dengan delapan pengujian, setiap pengujian sistem mengeluarkan solusi yang berbeda karena Algoritma Genetika pada pembangkitkan populasi awal dilakuakn secara acak.
Hasil yang didapat pada pengujian dengan menggunakan metode mutasi tiga kode subclass empat rute dan delapan rute dengan simulasi kapasitas 150 seat 100 generasi menghasilkan nilai kecocokan tertinggi yaitu $\mathrm{Rp}$. 763.265.300 pada pengujian kelima dengan metode mutasi tiga kode subclass pada delapan rute.

Hal ini membuktikan bahwa sistem optimalisasi distribusi harga tiket pesawat berdasarkan kepadatan rute mampu memberikan rekomendasi jumlah tiket pada subclass ekonomi dengan keuntungan yang optimal. 


\section{DAFTAR PUSTAKA}

[1] N. Sartika, "Penentuan subclasses berdasarkan tipe pesawat," Jurnal Manajemen Bisnis Transportasi dan logistik, vol. 1, pp. 121-131, 2014.

[2] R. A. Pratama, E. C. Djamal, and A. Komarudin, "Optimalisasi Pengantaran Barang dalam Perdagangan Online Menggunakan Algoritma Genetika," Seminar Nasional Aplikasi Teknologi Informasi (SNATi), pp. 11-15, 2017.

[3] S. Uyun and S. Hartati, "Penentuan Komposisi Bahan Pangan untuk Diet Penyakit Ginjal dan Saluran Kemih dengan Algoritma Genetika," Seminar Nasional Aplikasi Teknologi Informasi (SNATi), vol. 2011, no. Snati, pp. 17-18, 2011.

[4] E. Gautama, "Algoritma Genetika untuk Menyelesaikan Coinn Problem Aplikasi pada Mesin ATM," Jurnal Sistem Informasi (JSI), vol. 8, no. 2, pp. 1056-1068, 2016.

[5] J. Tong, C. Wu, H. Jiang, Y. Yu, and X. Rao, "Optimizing the path of seedling low-density transplanting by using greedy genetic algorithm," Computers and Electronics in Agriculture, vol. 142, pp. 356-368, 2017.

[6] F. Purwanto, E. C. Djamal, and A. Komarudin, "Optimalisasi Penempatan Halte Trans Metro Bandung Menggunakan Algoritma Genetika," Seminar Nasional Aplikasi Teknologi Informasi (SNATi), pp. 36-38, 2016.

[7] S. Dewi, E. C. Djamal, and R. Yuniarti, "Optimalisasi Penempatan Guru Sekolah Dasar di Kecamatan Cikajang Kabupaten Garut Menggunakan Algoritma Genetika," in Prosiding Seminar Nasional Komputer dan Informatika
(SENASKI), 2017, vol. 2017, pp. 105-108.

[8] I. Manggolo, M. I. Marzuki, and M. Alaydrus, "Optimalisasi Perencanaan Jaringan Akses Serat Optik Fiber To The Home Menggunakan Algoritma Genetika," InComTech, Jurnal Telekomunikasi dan Komputer, vol. 2, no. February, p. 2, 2017.

[9] R. Sulistiyorini and W. F. Mahmudy, "Penerapan algoritma genetika untuk permasalahan optimasi distribusi barang dua tahap," no. 12, 2015.

[10] N. M. Hasyim, E. C. Djamal, and A. Komarudin, "Optimalisasi Rute Obyek Wisata Di Bandung Raya Menggunakan Algoritma Genetika," Seminar Nasional Aplikasi Teknologi Informasi (SNATi), pp. 6-10, 2017.

[11] A. U. Khamidah, D. I. L. A. M.T, and I. W. J. M.T, "Optimasi Penyusunan Box Komponen Program Spirit di dalam Container untuk Meminimasi Space Kosong Menggunakan Algoritma Genetika," in e-Proceding of Engineering, 2016, vol. 3, no. 2, pp. 2890-2897.

[12] M. D. T. Ramuna and W. F. Mahmudy, "Optimasi Persediaan Barang Dalam Produksi Jilbab Menggunakan Algoritma Genetika," DORO: Repository Jurnal Mahasiswa PTIIK Universitas Brawijaya, no. 14, pp. 1-10, 2015.

[13] M. L. Shahab and Mohammad Isa Irawan, "Algoritma Genetika Ganda untuk Capacitated Vehicle Routing Problem," Jurnal Sains dan Seni ITS, vol. 4, no. 2, pp. 2-7, 2016.

[14] Hozairi, K. B. A, Masroeri, and M. I. Irawan, "Implementation of nondominated sorting genetic algorithm - Ii (NSGA-II) for multiobjective optimization problems on distribution of indonesian navy warship," Journal of Theoretical and Applied Information Technology, vol. 64, no. 1, pp. 274-281, 2014. 